\title{
Description of laboratory reared first zoea of Callinectes danae Smith (Crustacea, Decapoda, Portunidae)
}

\author{
Cheruparambil Sankarankutty ${ }^{1}$ \\ Sung Yun Hong ${ }^{2}$ \\ Kwang Bong Kim ${ }^{2}$
}

\begin{abstract}
A detailed description of laboratory reared first zoea larva of Callinectes danae Smith, 1869 is given. The larvae utilized for this study were reared in vitro in a special incubator. A comparison with larvae of other species is also attempted.

KEY WORDS. Decapoda, Portunidae, Callinectes danae, first zoea larva
\end{abstract}

The genus Callinectes Stimpson, 1860 is represented in the northeast of Brazil by C. bocourti A. Milne Edwards, 1879, C. danae Smith, 1869, C. exasperatus (Gerstaecker, 1856), C. larvatus (A. Milne Edwards, 1863) and C. ornatus Ordway, 1863 (COElHO et al. 1986; SANKARANKUTTY et al. 1991). More recently, C. maracaiboensis Taissoun, 1969 was also reported by SANKARANKUTTY et al. (1999).

Among the species of Callinectes, the larval stages of $C$. sapidus Rathbun, have been studied in detail by several authors (CHURCHILL 1942; HOPKINS 1944; Costlow \& Bookhout 1959; Bookhout \& Costlow 1977) and those of $C$. similis Williams by BookHouT \& CostLow (1977). The larval stages of $C$. danae remains unknown so far and the present study is intended to facilitate their identification in the plankton samples. A study of zooplankton of the estuary of Potengi, Natal (SANKARANKUTTY et al. 1995) showed that most of the larvae of Brachyura encountered in the samples were unidentifiable due to the lack of description and therefore, culture of larvae in the laboratory from known adult is essential for the identification of these larvae.

\section{MATERIAL AND METHODS}

Ovigerous females were collected from the estuary of Potengi, Natal in November 1997 and live eggs were removed from the female and reared in a special incubator (Fig. 1). The incubator is in the form of a square tray made of perspex sheets $(6 \mathrm{~mm}$ in thickness) with a depth of $10 \mathrm{~cm}$. The bottom of the incubator is provided with two rows of three holes through which a tube $(F)$ is introduced. The incubator has an inlet tube (D) on one side near the bottom for entrance of water and an exit tube (E) near the top for overflow of excess water. Six containers (C)

1) Departamento de Oceanografia e Limnologia, Universidade Federal do Rio Grande do Norte. Praia de Mãe Luiza, Via Costeira, 59014-100 Natal, Rio Grande do Norte, Brasil.

2) Department of Marine Biology, Pukyong National University. 608-737 Pusan, Korea. 
B

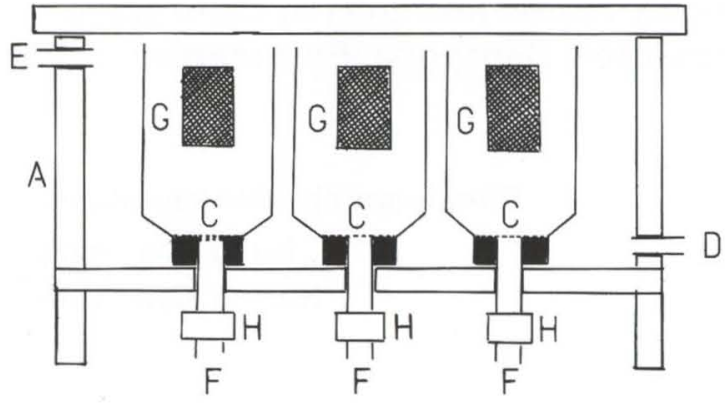

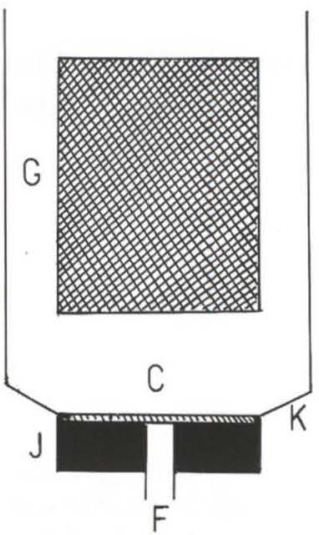

Fig. 1. Incubator used for culturing eggs in vitro.

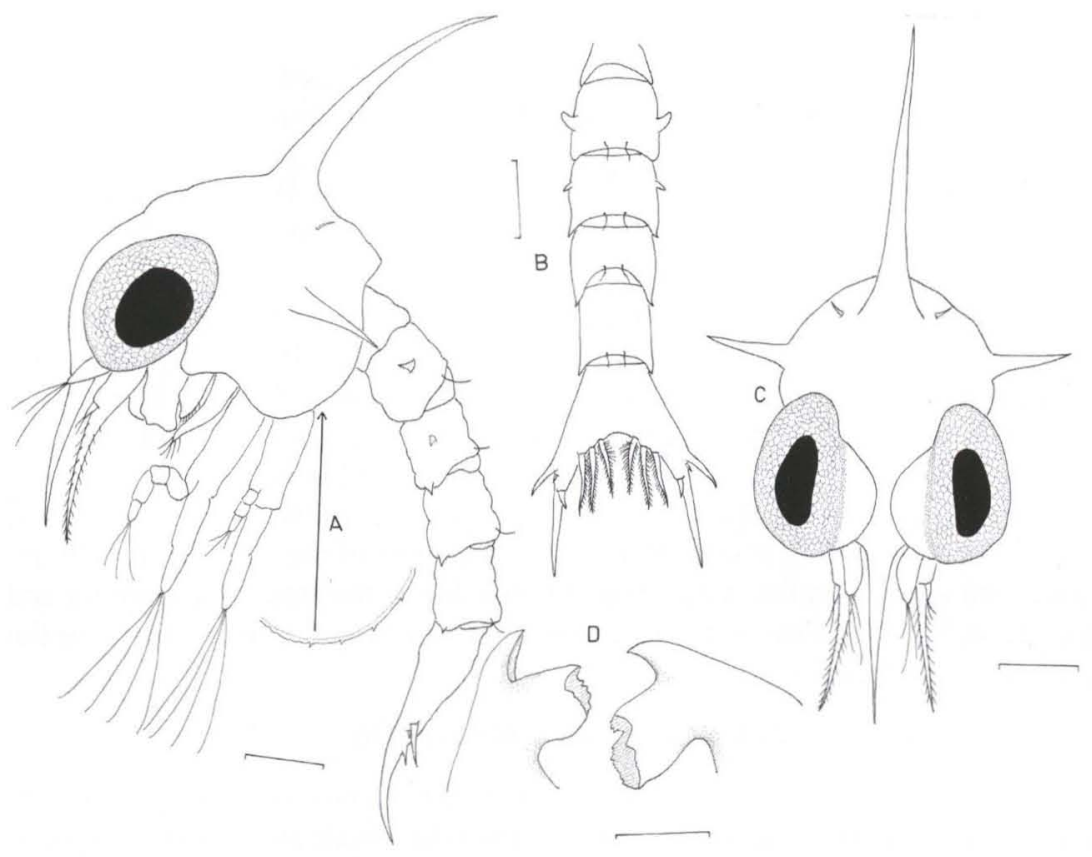

Fig. 2. First zoea of Callinectes danae. (A) Lateral view of larva; (B) abdomen with telson; (C) frontal view of larva; (D) mandibles. Scales: $(A, B, C) 0.1 \mathrm{~mm}$, (D) $0.05 \mathrm{~mm}$.

are utilized in each incubator. A polythene bottle of $100 \mathrm{ml}$ capacity is utilized as containers, the bottom of these bottles are cut off and the cap of the bottle $(\mathrm{J})$ with a hole in the middle is fixed above each hole of the incubator with araldite. A piece of plankton net $(\mathrm{K})$ is placed inside the cap. The body of the bottle is provided with two windows on opposite sides, each covered with a piece of plankton net $(\mathrm{G})$. The bottle is screwed on the fixed cap inside the incubator. The incubator receives water 
by gravity from a reservoir ( 10 litres capacity) placed at a higher level. The pipes (F) provide a steady flow of air controlled by a stopper $(\mathrm{H})$. The incubator is covered with a lid (B) of perspex sheet.

The eggs removed from the females were placed in each container (about 20 in each). The incubator was set up by filling them with water drawn from the larger container through the pipe (D) and excess water drains off through outlet (E). The container inside the incubator gets a free exchange of water through the windows (G). The air supplied through the tube (F) keeps the eggs constantly aerated and agitated within the container, the bolting silk at the bottom of the container $(\mathrm{K})$ retains the eggs within the container. The water inside the incubator was renewed once every day.

The system adopted here has basically two advantages. It can be used for incubating eggs in vitro without having to maintain the adult alive since the eggs are kept well oxygenated and agitated. Secondly, the exchange of water within the incubator can be carried out without disturbing the system.

\section{Description of first zoea}

Measurements of larva (in $\mathrm{mm}$ ): carapace length 0.437 ; length of abdomen 0.370 ; length of telson 0.303 ; length of dorsal spine 0.351 ; length of rostral spine 0.215 ; length of antenna 0.248 .

Carapace (Fig. 2A,C): with dorsal, rostral and lateral spines; dorsal spine curved backwards and distinctly longer than rostral spine, lateral spine short; a spinule on either side and located behind dorsal spine; postero-lateral margin with four to five minute spinules.

Antennule (Fig. 3A): oblong in shape, about twice as long as broad, with two aesthestacs and a shorter spine.

Antenna (Fig. 3B): spinous process much longer that exopod and with two series of spinules; exopod with two unequal distal setae; spiny process with two series of spinules. absent.

Mandible (Fig. 2D): Incisor and molar processes well developed; palp

Maxillule (Fig. 4B): Two-segmented endopod with four terminal of unequal size and one subterminal setae; coxal endite with five and basal endite with four setae.

oMaxilla (Fig. 3C): Scaphognathite with four marginal setae and one plumose seta psteriorly. Endopod unsegmented but bilobed distally with two and three setae on proximal and distal lobes. Coxal endite and basal endites bilobed, former with three and two setae (proximal and distal lobes respectively) and latter with four setae on each lobe.

Maxilliped 1 (Fig. 3C): 5-segmented endopod with 1, 1, 0, 2, 5 setae on segments 1 to 5 ; basis with setae in groups of 2,2,2,2; exopod with four natatory setae.

Maxilliped 2 (Fig. 3A): 3-segmented endopod with 1, 1, 4 setae. Basis with three setae and four natatory setae on exopod. 


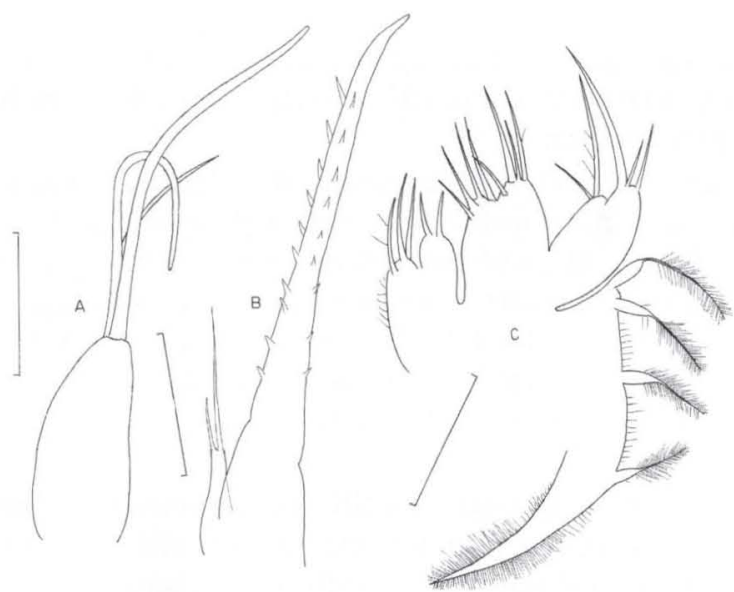

Fig. 3. First zoea of Callinectes danae. (A) Antennule; (B) antenna; (C) Maxilla. Scale $0.05 \mathrm{~mm}$.

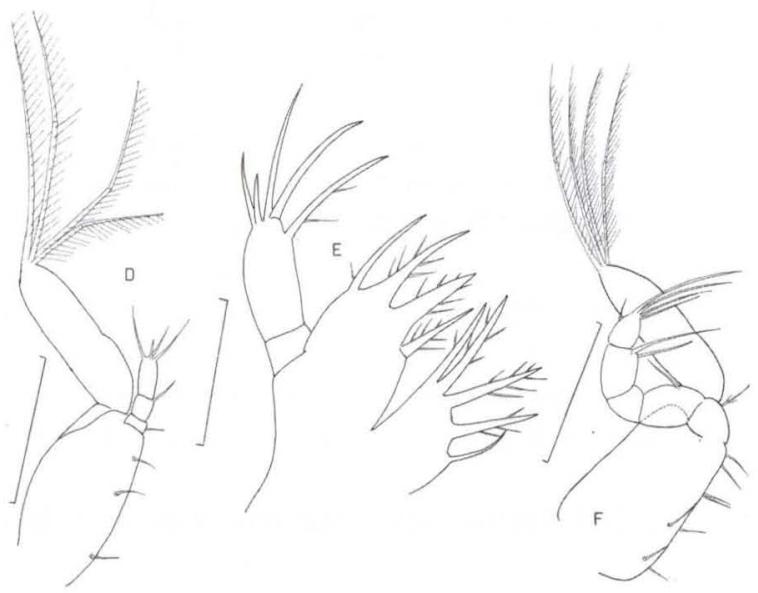

Fig. 4. First zoea of Callinectes danae. (A) Maxilliped 2; (B) maxillule; (C) maxilliped 1. Scales: (B) $0.05 \mathrm{~mm},(A, C) 0.1 \mathrm{~mm}$.

Abdomen (Fig. 2B): consisting of five segments excluding telson. Second and third segments with lateral lobes, those on second larger, curved and directed anteriorly and those on third directed posteriorly. $3^{\text {rd }}-5^{\text {th }}$ segments with small spines on posterolateral angles; a pair of spinules dorsally near posterior border on segments $2-5$.

Telson (Fig. 2B): with deep furca; large lateral spine on furca placed closer to base of furca, minute secondary spinule near base of lateral spine; additional spinule on the dorsal surface of furca placed slightly distal and close to base of lateral spine; posterior margin with three pairs of setae. 


\section{DISCUSSION}

Though the larva of $C$. danae resembles in several aspects those of $C$. sapidus and $C$. similis, we have been able to identify certain features which are characteristic of its larvae. (1) Four to five spinules on the posterolateral margin of carapace has been observed only in $C$. danae. (2) an additional spinule on the dorsal surface of the furca of telson is characteristic of $C$. danae. (3) reduced number of aesthetascs and other setae on antennule (4) maxillule in $C$. danae has only five setae on endopodite while both $C$. sapidus and $C$. similis have 6 setae each (5) basal endite of maxillule in $C$. danae has four setae while $C$. sapidus and $C$. similis have five setae each (6) while $C$. sapidus and $C$. similis have identical setal formula of maxilliped 1 of 2, 2, 0, 2, 5, that of $C$. danae is $1,1,2,0,2,5$.

ACKNOWLEDGEMENTS. The senior author is grateful to CNPq for the fellowship, to Dr. S.Y. Hong for extending an invitation to visit his laboratory and CAPES for providing air passage which facilitated his visit to Korea.

\section{REFERENCES}

Bookhout, C.G. \& J.D. CostLow JR. 1977. Larval development of Callinectes similis reared in the laboratory. Bull. Mar. Sci. 27: 704-728.

Churchill, E.P. 1942. The zoeal stages of the blue crab, Callinectes sapidus Rathbun. Chesapeake Biol. Lab. 49: 1-26.

Coelho, P.A.; M. Ramos-Porto \& T.C.S. Calado. 1986. Litoral do Rio Grande do Norte: Decapoda. Cad. Omêga Univ. Fed. Rural Pernambuco, Sér. Ci. Aquát., Recife, (2): 79-105.

CostLow JR., J.D. \& C.G. Bookhout. 1959. The larval development of Callinectes sapidus Rathbun reared in the laboratory. Biol. Bull. 116: 373-396.

HoPKINS, S.H. 1944. The external morphology of the third and fourth zoeal stages of the blue crab, Callinectes sapidus Rathbun. Biol. Bull. 87: 145-152.

SankarankutTy, C.; A.G. Freire \& L.C. Santiago. 1991. On the taxonomy and distribution of Callinectes Stimpson (Crustacea, Decapoda, Portunidae) in Rio Grande do Norte. Revta bras. Zool. 5: 7-22.

Sankarankutty, C.; A.C. Ferreira; C.S.C. Pinto; F.E.N.V. BarCa \& M.A. AlENCAR. 1999. Callinectes maracaiboensis Taissoun (Crustacea, Decapoda, Portunidae), a species common but so far unrecorded from the northeast of Brazil. Revta bras. Zool. 16 (1): 145-150.

SankarankutTy, C.; J.E. Lins Oliveira; K.M.F. Cunha; A.C.C. Silva \& E.V.G. ARROCA. 1995. Further observations on zooplankton of the Potengi estuary (Natal, Brazil), with special reference to the larvae of Brachyura (Crustacea, Decapoda). Revta bras. Zool. 12: 273-301. 